\title{
XIV Międzynarodowa Konferencja ISKO "Knowledge Organization for a Sustainable World: Challenges and Perspectives for Cultural, Scientific, and Technological Sharing in a Connected Society"
}

\author{
(Rio de Janeiro, 27-29 września 2016)
}

XIV Międzynarodowa Konferencja International Society for Knowledge Organization (ISKO) w dniach 27-29 września 2016 r. zgromadziła w Rio de Janeiro w Brazylii ponad stu uczestników z 17 krajów. Brazylia to piąty co do wielkości kraj świata. Brazylijczycy mawiają, że Bóg stworzył świat w ciągu sześciu dni. Siódmy poświęcił na Rio de Janeiro. Położone bardzo malowniczo miasto jest obdarzone wszelkimi cechami raju. Czuwa nad nim na granitowej górze Corcovado olbrzymia figura Chrystusa Zbawiciela z rozpostartymi ramionami. Głowę i dłonie statui wyrzeźbił w 1931 r. francuski artysta polskiego pochodzenia Paul Landowski. Spod tego pomnika rozciągają się wspaniałe widoki na okoliczne wzgórza, miasto, Głowę Cukru, słynny stadion piłkarski Maracanę, międzynarodowe lotnisko oraz przepiękne plaże Copacabanę i Ipanemę. Ten kolorowy kulturowo zróżnicowany raj jest jednak pełen kontrastów. Pełne przepychu apartamenty sąsiadują tu z dzielnicami nędzy i występku, tzw. favelami.

Celem tegorocznej konferencji ISKO była naukowa debata na temat obecnych wyzwań i perspektyw dalszego rozwoju organizacji wiedzy (OW) właśnie w kontekście różnorodności kulturowej, weryfikacja aktualnego stanu badań w zakresie organizacji wiedzy, wyznaczenie nowych perspektyw naukowego dialogu w międzynarodowym środowisku badaczy tego obszaru wiedzy, przedyskutowanie jego epistemologicznej struktury, możliwości interdyscyplinarnego dialogu, wdrożenia najnowszych aplikacji technologicznych i zdefiniowania społecznego wymiaru OW, a także wzmocnienia międzynarodowej współpracy i widoczności badań naukowych w zakresie OW.

Otwarcia tegorocznego spotkania w bardzo nowoczesnych budynkach prestiżowej Fundação Getulio Vargas dokonał obecny prezydent ISKO prof. Joseph T. Tennis (University of Washington, Seattle, USA) oraz przewodniczący oddziału ISKO w Brazylii prof. José Augusto Chaves Guimarães (São Paulo State University, Marilia, Brazylia).

Przewodni temat konferencji Knowledge Organization for a Sustainable World: Challenges and Perspectives for Cultural, Scientific, and Technological Sharing in a Connected Society stanowił inspirację do 70 wystąpień, które w ciągu trzech dni zaprezentowano równolegle w trzech blokach tematycznych: (1) wymiar epistemologiczny organizacji wiedzy - 26 wystąpień (konceptualne, historyczne, metodologiczne podstawy organizacji wiedzy - także na przecięciu różnych dyscyplin); (2) wymiar stosowany - 30 wystąpień (modele organizacji wiedzy, formaty, narzędzia, produkty i struktury), a także (3) perspektywa społeczno-polityczna - 14 wystąpień (w tym zagadnienia edukacji i profesjonalnej praktyki, etyki, kultury oraz zrównoważonego rozwoju).

W kontekście wyzwań i perspektyw zrównoważonego rozwoju stawiano pytania o to jak organizacja wiedzy - jako dyscyplina badawcza i jako wspólnota badaczy - może zaadaptować się do obecnie zachodzących zmian w dziedzinie nauki na świecie i w jaki sposób mogą one zostać włączone do koncepcji projektowania i wykorzystywania systemów organizacji wiedzy; w jaki sposób organizacja wiedzy wpływać może na obecny świat nauki? 
Do wygłoszenia inauguracyjnego wykładu w sesji plenarnej (The Integration of Culture in Knowledge Organization Systems) zaproszona została prof. Maria J. Lopez-Huertas (University of Granada, Hiszpania), która w swoim wystąpieniu zwróciła szczególną uwagę na obecność różnych wymiarów kultury w organizacji wiedzy oraz systemach organizacji wiedzy - SOW (Knowledge Organization Systems - KOSs). Jej postulat integracji kultury w globalnych SOW dotyczył zarówno integracji różnych subkultur w ramach jednej wspólnej kultury, jak i integracji różnych kultur w uniwersalnym SOW.

Drugą część obrad plenarnych stanowiły wystąpienia w ramach 90-minutowego tzw. okrągłego stołu na temat KO for a Sustainable World: ISKO Perspectives, moderowane przez prof. D. Granta Campbella (University of Western Ontario, London, Kanada). Celem tej dyskusji była prezentacja przez koordynatorów - prezydentów poszczególnych narodowych oddziałów - ich wizji międzynarodowej działalności ISKO oraz działalności ich oddziałów. Do wypowiedzi na temat perspektyw dalszego rozwoju OW zostali zaproszeni Prezydent ISKO oraz koordynatorzy narodowych oddziałów ISKO z Brazylii (José Augusto Chaves Guimarães), Francji (Widad Mustafa El Hadi), Hiszpanii (Isidoro Gil Leiva), Indii (K.S. Raghavan), Niemiec (H. Peter Ohly), Polski (Wiesław Babik), USA (Joseph T. Tennis) i Wielkiej Brytanii (Stella Dextre Clarke). Szczegółowe pytania, które postawiono w dyskusji to:

- Jak należy rozumieć termin „zrównoważony system organizacji wiedzy” (ang. sustainable knowledge organization system)?

- Co można i należy uczynić, aby funkcjonujące w XXI wieku uniwersalne systemy organizacji wiedzy jak DDC, UDC i LCC stały się „sustainable” (rozwijały się trwale)?

- Co należy robić, aby równoważona (ang. sustainable) ludzka działalność minimalizowała postępującą degradację środowiska informacyjnego?

- W jaki sposób działalność i badania naukowe ISKO mogą przyczynić się do globalnego równoważenia rozwoju środowiska informacyjnego?

W trakcie obrad okrągłego stołu postawiono więc pytania o współczesne rozumienie terminu „organizacja wiedzy", dynamiczne zmiany zachodzące w OW i ISKO, a w związku z tym, jak skutecznie promować tę dyscyplinę oraz w jakim kierunku powinny zmierzać działania ISKO i badania nad OW w przyszłości. Zasygnalizowano podjęcie przez ISKO opracowania Encyclopedia of Knowledge Organization.

Najbardziej widoczne konteksty brazylijskiej konferencji stanowiły: kulturowa różnorodność, międzynarodowość, globalizacja, zrównoważony rozwój oraz metodologiczny pluralizm. W wymiarze praktycznym za słowa-klucze konferencji z pewnością można uznać ontologie oraz sieci semantyczne.

Na zakończenie obrad konferencji poinformowano o wyłonionym w konkursie na najlepszy zdaniem specjalnego jury - tekst opublikowany w wydrukowanych przez Ergon Verlag materiałach tej konferencji. Zwycięzcą została Ann M. Graf z USA (University of Wisconsin-Milwaukee), która w tekście Describing an Outsider Art Movement from Within: The AAT and Graffiti Art zaprezentowała wyniki badań nad tym, jak swoje działania i produkty opisuje w czasopismach wspólnota artystyczna skupiona wokół graffiti i na ile przoduje na tym polu Getty Research Institute's Art and Architecture Thesaurus (AAT).

Warto odnotować wygłoszone i opublikowane referaty trzech polskich naukowców: Wiesława Babika (UJ): Information Logistics: Usability in Knowledge Organization, Katarzyny Materskiej (UKSW): Knowledge Organization in University Repositories in Poland oraz Marcina Roszkowskiego (UW) (wspólnie z Widad Mustafa El Hadi Université Liile 3 Francja): The Role of Digital Libraries as Virtual Research Environments for the Digital Humanities.

Pokłosiem konferencji jest wspomniana 600-stronicowa publikacja, wydana przez Ergon Verlag w serii Advances in Knowledge Organization, vol. 15, której redaktorami są brazylijscy akademicy: 
José Augusto Chaves Guimarães, Suellen Oliveira Milani oraz Vera Dodebei ${ }^{1}$. Jest ona dostępna w wersji papierowej i elektronicznej - dla członków ISKO w postaci elektronicznej na portalu Ergon - Services for ISKO members (http://www.ergon-verlag.de/isko_ko/).

Świetne przygotowanie konferencji jest zasługą brazylijskiego oddziału ISKO, w tym studentów Graduate School of Information Science of São Paulo State University. Konferencji towarzyszyła bardzo przyjazna atmosfera, a jej uczestnicy mieli okazję nawiązać wiele nowych kontaktów naukowych i prywatnych znajomości. Dobremu nastrojowi sprzyjały przepiękne widoki i liczne turystyczne atrakcje wspaniałego Rio de Janeiro.

Następna, XV już Międzynarodowa Konferencja ISKO odbędzie się za dwa lata w Porto (Portugalia) od 9 do 11 lipca $2018 \mathrm{r}$.

Wiesław Babik (Krajowy Koordynator ISKO w Polsce) Instytut Informacji Naukowej i Bibliotekoznawstwa, Uniwersytet Jagielloński

Katarzyna Materska (Sekretarz Polskiej Sekcji ISKO) Biblioteka Gtówna Uniwersytetu Kardynała Stefana Wyszyńskiego w Warszawie

Nadesłano: 11 stycznia 2017.

\section{Międzynarodowa Konferencja „Digital Humanities Centres: Experiences and Perspectives"}

(Warszawa, 8-9 grudnia 2016 r.)

W dniach 8-9 grudnia 2016 roku w Warszawie odbyła się międzynarodowa konferencja naukowa pt. „Digital Humanities Centres: Experiences and Perspectives”. Konferencję zorganizowało Laboratorium Cyfrowej Humanistyki Uniwersytetu Warszawskiego (LACH UW) pod patronatem Alliance of Digital Humanities Organizations (ADHO), Digital Research Infrastructure for the Arts and Humanities (DARIAH EU), Ministerstwa Nauki i Szkolnictwa Wyższego oraz Ministerstwa Cyfryzacji. Humanistyka cyfrowa (ang. $D H$ ) budzi coraz szersze zainteresowanie wśród naukowców i staje się tematem licznych konferencji. Tym bardziej warto zauważyć, że konferencja „Digital Humanities Centres: Experiences and Perspectives” jest pierwszą europejską konferencją poruszającą wyłącznie aspekt instytucjonalizacji cyfrowej humanistyki.

Podczas czterech sesji, poprowadzonych w ciągu dwóch dni konferencji, zaprezentowano 17 referatów badaczy z Europy, Stanów Zjednoczonych oraz Azji. Sesje otwierały wykłady gości specjalnych, o które poproszono prof. Frédérica Kaplana z Ecole Polytechnique Federale de Lausanne, prof. Gerharda Lauera z Georg-August-Universität Göttingen, prof. Jana Christopha Meistera z Universität Hamburg oraz prof. Susan Schreibman z Maynooth University. Zaproszeni prelegenci na co dzień kierują pracami wiodących instytucji cyfrowej humanistyki w Europie.

\footnotetext{
${ }^{1}$ Knowledge Organization for a Sustainable World: Challenges and Perspectives for Cultural, Scientific, and Technological Sharing in a Connected Society. Proceedings of the Fourteenth International ISKO Conference 27-29 September 2016 Rio de Janeiro, Brazil. Organized by International Society for Knowledge Organization (ISKO) ISKO-Brazil São Paulo State University. Edited by José Augusto Chaves Guimarães, Suellen Oliveira Milani and Vera Dodebei. Würzburg: Ergon Verlag GmbH 2016, pp. 601.
} 